\title{
Rettferdige minutter: Fordeling av spilletid i fotballkamper for aldersbestemte klasser
}

\section{Trine Anker}

På et fotballag $i$ overgangen mellom barne- og ungdomsfotballen er spilletid på fotballbanen under kamp både en knapp ressurs og en kilde til diskusjoner om fordeling. Spørsmålet som er utgangspunkt for denne artikkelen, er hvilke hensyn som bør tas når trener og lagleder skal fordele samlet spilletid $p a ̊$ enkeltspillere. Er det viktigst å vinne fotballkampen, eller har det størst betydning å fordele spilletiden mest mulig likt mellom spillerne? Skal det tas hensyn til guttenes evner, motivasjon og preferanser? Er deres familiebakgrunn og personlighet av betydning? Diskusjonen baserer seg på en gjennomgang av ulike politiske rettferdighetsteorier for fordeling av knappe goder.

Nøkkelord: rettferdighet, practice, fordelingsrettferdighet, diskursetikk, idrettsetikk

English summary: Minutes of justice: Distribution of time during football matches in a boys' team

During a football match, time for playing can be considered as a limited good. In this article the point of departure is the redistribution of time in a boys' football team in the transition phase between children and youth football. The questions are how and under which conditions time for playing should be distributed among the players. Is winning the game more important than trying to let every player play for an equal amount of time? Should the boys' talents, motivation, and preferences be considered while distributing time, or are family background and personality of importance? Different theories of political justice for the distribution of limited goods underpin the discussion of how to distribute the minutes of playing time during a football match.

Keywords: distributive justice, practice, discourse ethics, sport ethics, capabilities 


\section{Innledning}

Bredde eller elite? I norsk samfunnsdebatt settes ofte bredde- og elitetenkningen i organisering av barne- og ungdomsfotballen opp som sterke motpoler. Breddetenkerne framstilles som offer for norsk jantelov, mens eliteentusiastene beskyldes for å undergrave et tilbud om idrett for de fleste. I tillegg er det også uenighet om det er bredde- eller eliteprofil i barnefotballen som gir best rekruttering til elitefotball på seniornivå. Ettersom barnefotballen er så stor i Norge og engasjerer en høy prosentandel av barn i idrett, har den også et etisk ansvar for hvordan den forvalter denne ressursen gjennom ungdomsårene. Fordeling av spilletid i fotballkamper er en viktig symbolsak for diskusjonen om bredde kontra elite. Dette har ført til at Norges fotballforbund (NFF) har klare regler mot topping av laget for barnefotballen. I ungdomsfotballen, derimot, eksisterer ikke disse reglene, og det er opp til trener å vurdere og bestemme spilletid. ${ }^{1}$ Overgangen mellom barne- og ungdomsfotballen som skjer i 13-årsalderen (fra 7'er til 11 'er-fotball), kan derfor resultere i et markant brudd med regler som er ment å sikre bredden i fotballagene. Mange slutter å spille fotball i denne overgangsfasen (Storø 2007: 20). ${ }^{2}$ Jeg ønsker å få fram kompleksiteten i vurderinger av spilletid, og mener at overgangen fra å spille etter en definert breddeprofil til mer utpreget elitetekning bør skje gradvis. Barnefotballen bør gjennom en mer kompleks diskusjon av hva rettferdig fordeling av spilletid er, nedtone noe betydningen av lik spilletid, mens ungdomsfotballen på den annen side burde reflektere mer over det etiske ansvaret som ligger i fordeling av spilletid og topping av laget.

I denne artikkelen skal jeg diskutere nettopp denne fordelingen av spilletid i kamper. Konteksten er et fotballag bestående av gutter som er 12 år gamle, det vil si at de er i overgangsfasen mellom barnefotballens strenge regulering av spilletid og ungdomsfotballens mangel på regulering.

Spilletid i kamp for dette laget ble opprinnelig fordelt av trener og lagleder med resultater som eneste begrunnelse for fordelingen, stikk i strid med NFFs regler. Dette førte til mange seirer, men også til misfornøyde spillere som sjelden fikk spille i fotballkampene. Kampene er det store målet med treningen, og spillere som fikk liten eller ingen tid under kamp, begynte å uttrykke misnøye. Foreldrene innkalte til et møte, hvor de med utgangspunkt i fotballforbundets regler som forbyr topping av laget i denne årsklassen, forlangte en ny fordeling av spilletid i kamper. Ettersom laget er på vei inn i ungdomsfotballen der regelen mot topping ikke gjelder, ble diskusjonen om fordeling gjort med tanke på å finne en profil som kunne brukes framover. Spørsmålet for min drøfting blir derfor: Hvordan kan tiden mellom spillerne fordeles på en mer rettferdig måte?

Målet med barne- og ungdomsfotballen er å bygge en positiv fotballkultur som er mer langsiktig enn resultatene fra den enkelte kamp. Denne fotballkulturen bør bestå både av et anerkjennende miljø og av en stadig forbe- 
dring og perfeksjonering av spillet til samtlige spillere ut fra deres forutsetninger. Fotballspillet kan derfor defineres som en "practice» i MacIntyres forstand, der laget gjennom samarbeid prøver å nå nye høyder. Gjennom spillet vil spillerne både kunne oppnå eksterne goder (score et mål) og de enda viktigere interne godene som perfeksjonering av spillet og samarbeid om å vinne en kamp (jf. MacIntyre 1985: 187-190). De eksterne og interne målene kan innimellom framstå som motsetninger. Lar vi den største målscoreren spille hele tiden uten tanke på samspillet for øvrig, kan eksterne goder bli satt foran interne. Imidlertid er det å forsøke å vinne kamper avgjørende for fotballspillet. Den som ikke prøver å vinne, spiller ikke fotball.

Ettersom laget består av mange gutter, og en fotballkamp varer en begrenset tid, kan spilletid i kamp oppfattes som et knapt gode. Derfor ønsker jeg å drøfte fordeling av spilletid med utgangspunkt i rettferdighetsteori. En naturlig innvending til valg av tilnærming er at det kan virke søkt å anvende teorier som er ment å si noe om storsamfunnet på et mikronivå som et fotballag. Ifølge Rawls kan ikke et politisk samfunn være en «association». Vi befinner oss i et spesielt politisk samfunn en viss periode av historisk tid - det er ikke noe vi bevisst har valgt (Rawls 2001: 4). Et fotballag er en frivillig organisasjon, guttene som spiller der har valgt fotballen (med mer eller mindre press fra foreldre), og de kan når som helst trekke seg ut. Lagleder kan sies å være valgt (selv om det i realiteten gjerne er den ene som melder seg), men da av barnas foreldre. Jon Elster hevder at rettferdighetsteorier som utilitarisme og John Rawls' teori hjelper lite i konkrete fordelingssituasjoner, og at vi i praksis må følge andre og mer håndfaste prinsipper (Elster 1990: 325).

Jeg mener allikevel at en slik diskusjon kan vise noen av de allmenne problemstillingene om rettferdighet også ved «lokal rettferdighet», og at det derfor kan være interessant og relevant å se disse teoriene i mikroperspektiv. Artikkelen preges dermed av bredde framfor dybde fordi jeg har ønsket å trekke fram flere og ulike perspektiver på rettferdig fordeling.

\section{Fordeling av spilletid}

\section{Lik fordeling av spilletid}

Fordeling av spilletid i en fotballkamp kan sies å befinnes seg i feltet fordelingsrettferdighet (distributiv rettferdighet). Fordelingsrettferdighet kan defineres som rettferdig fordeling av knappe goder. Hvem skal få hva, når, hvor, hvor mye, og hvordan. I dette tilfellet er det knappe godet antall minutter spilletid. Det er tolv spillere på laget og sju spillere på banen samtidig. Fotballkampene varer i til sammen 2 x 30 minutter. Ifølge det formelle rettferdighetsprinsippet som kan føres tilbake til Aristoteles, skal like 
tilfeller behandles likt, og ulike tilfeller behandles ulikt (Feinberg 1973: 100). Det enkleste er kanskje å definere disse tilfellene (altså spilleres forhold til spilletid) som like, og fordele spilletiden etter brøken $(2 \times 30$ min.: 12 spillere) x $7=35 \mathrm{~min}$. for hver spiller. En annen måte å fordele likt på er å si at det bare er sju spillere som skal spille en kamp. Disse sju kan plukkes ut ved loddtrekning eller terningkast. Da følger spørsmålet om vi i neste kamp skal rullere, slik at alle spillere får spilt i løpet av to kamper, eller om det skal være en ny loddtrekning for hver kamp. Ved gjennomføring av sistnevnte forslag risikerer vi at noen er uheldige, og derved ikke får spille så mange kamper. Dessuten kan farene for skader øke ved ikke å bruke innbyttere. Det vil nok derfor være best med en rullerende ordning. Det en slik likhetsmodell imidlertid ikke tar hensyn til, er spillernes ulike kvalifikasjoner og innsats.

\section{Ulik fordeling av spilletid}

Ifølge Aristoteles er det en allmenn oppfatning at rettferdig fordeling betyr at enhver får etter fortjeneste i en eller annen forstand. Det finnes imidlertid delte meninger om hva slags fortjeneste det skal være snakk om (Aristoteles 1973: 47). Det aktuelle fotballaget er sammensatt av spillere med svært ulik motivasjon, evner og innsats. Det er derfor ikke nødvendigvis mest rettferdig å fordele tiden jevnt på alle spillerne. Å behandle ulikemenn ulikt betyr ikke at likhetsprinsippet oppgis. Aristoteles legger derimot vekt på en proporsjonal likhet. Den som har gjort seg fortjent til mye, får mye, mens den som har gjort seg fortjent til lite, får lite (Aristoteles 1973: 49). Hvilken fortjeneste eller hvilke kriterier som skal legges til grunn, blir derfor et avgjørende spørsmål. Noen aktuelle kriterier kan være følgende:

1 De som har mest behov for fotballen (f.eks. barn som lider av omsorgssvikt, har problemer på skolen, eller de dårligste spillerne, som trenger mest trening)

2 De som legger ned mest arbeid (les: trening) i fotballen

3 De som er mest aktiv på kampene

4 De beste spillerne

5 De som har størst betalingsvillighet (som satser mest på alltid å være med, samt foreldres innsats på dugnader)

(Bygget på Feinberg 1973: 109-119)

Målet med fotballaktiviteten er både å vinne enkeltkamper, å øke ferdighetsnivået samt å motivere barna for å fortsette med fotball. Det kan føre til en konflikt mellom prosess og resultat - den langsiktige utviklingen av fotballferdigheter kontra den kortsiktige ved å vinne enkeltkamper. 
Hvis vi fordeler spilletiden ujevnt, og lar de som er best til å spille og de som yter maksimalt på banen, få mest spilletid, vil vi også øke sjansene for å vinne. Det kan virke motiverende for hele laget. Det kan derfor være et poeng å la de flinkeste og de ivrigste få spille mest. Klassisk utilitarisme hevder at målet er å maksimere lykken for flest mulige. Dersom det forutsettes at de fleste av spillerne ønsker å vinne, og at de gjennom deltakelse på laget får del i seieren, kan det rettferdiggjøres at ikke alle får like mye spilletid. De beste kan med et slikt utgangspunkt prioriteres, slik at laget vinner flere kamper.

\section{Rimelig fordeling av spilletid}

John Rawls kritiserer det utilitaristiske synet på helheten framfor enkeltindividet. Det øverste målet med kampen er fortsatt motivasjon, og vi kan tenke oss at selv om ujevn fordeling av spilletid fører til seier, fører det ikke nødvendigvis til økt motivasjon hos de dårligste. De kan like gjerne bli umotiverte av å få lite spilletid. Hvordan skal så denne oppgaven løses hvis vi prøver oss på en Rawls-tilnærming?

Rawls' to prinsipper for at rettferdighet er rimelig («justice as fairness»), er følgende:

1 Alle har lik rett til de samme grunnleggende friheter (frihetsprinsippet).

2 a. Alle skal ha de samme mulighetene (prinsippet om sjanselikhet), og

b. Forskjeller kan godtas dersom de som er minst heldig stilt får størst mulige fordeler (ulikhetsprinsippet). (Rawls 2001)

I fordeling av spilletid vil de minst heldig stilt være de dårligste spillerne med minst spilletid. Ifølge ulikhetsprinsippet til Rawls skal endringer føre til at disse spillerne får det bedre, selv om det går noe på bekostning av de best stilte. Hvordan den konkrete fordelingen av tid skal skje, og hvilke hensyn som skal veie tyngst, avgjøres ifølge Rawls gjennom diskusjon. Han sier at man skal komme fram til den mest rettferdige ordningen ved å diskutere seg fram til den under visse forutsetninger. De som deltar, må være frie og likeverdige; altså skal forholdet dem imellom være symmetrisk. Samtidig forutsettes det at deltakerne har en utviklet rettferdighetssans og handler etter ideen om det gode liv. Når disse forutsetningene er på plass, må deltakerne i forhandlingen innta den opprinnelige posisjon. Det betyr at det sees bort fra individuelle forskjeller, og man kommer fram til avtaler under et slør av uvitenhet («veil of ignorance»). Sløret av uvitenhet betyr at man ikke selv har informasjon om ens egen klasse, kjønn, etnisk og religiøs tilknytning etc. Overført til fotballaget vil det si at for å komme fram til prinsipper om fordeling av spilletid vil avtaleinngåerne ikke vite om de representerer de dårligste, de beste eller de ivrigste. Under dette sløret av uvitenhet hevder Rawls at konklusjonen vil bli at de dårligst stilte bør få det 
bedre, selv om det går noe på bekostning av de bedre stilte. Det vil medføre at deltakerne blir enige om at de som alltid har spilt minst, skal få spille noe mer. Det vil ikke være akseptabelt at noen spillere står på sidelinja hele kampen. Disse retningslinjene gjelder selv om det går utover de beste som derved får spille færre antall minutter, samt at laget ikke oppnår like gode resultater som tidligere. Rawls' diskusjon under sløret av uvitenhet løser imidlertid ikke problemet med hvor mye spilletid som skal tildeles den enkelte. Vi kunne også tenkt oss et system der vi ble enige om et minsteantall minutter for hver spiller, mens tiden utover dette ble fordelt på de beste. Det ville sikret alle spilletid, og det ville bli tatt hensyn til kampenes resultater. En slik terskelnivåtenkning står blant andre Amartya Sen og Martha Nussbaum for (jf. nedenfor). Resultatene av en Rawls-diskusjon trenger ikke å bli så veldig annerledes, men Rawls er ikke opptatt av å sette terskelnivå. Det at de dårligst stilte får det bedre, er hans krav, ikke at de skal ha en terskel for en minstestandard. På dette fotballaget hadde noen av spillerne minimalt med spilletid. Det vil si at kun en liten økning til for eksempel 2 minutter per kamp er innenfor Rawls' definisjon av rettferdighet dersom tidsdelingen er diskutert fram av spillerne selv, uten tanke på egne prestasjoner eller ferdigheter.

Seyla Benhabib kritiserer Rawls og hele den fornuftsbaserte kantianske tradisjonen. Hennes ankepunkt er at følelser og opplevelse settes til side, og hun hevder at det ikke er mulig å følge Rawls' idé om å diskutere seg fram til rettferdighet under et slør av uvitenhet. Tar man bort historie, minner, relasjoner til andre etc. står man igjen med en tom maske som er alle og ingen (Benhabib 1992: 161). Benhabib kritiserer derved tanken om den generaliserte andre og lanserer selv en rettferdighetsteori som bygger på den konkrete andre. Med den konkrete andre mener hun mennesker som har en historie, og som også har følelser for og relasjoner til andre mennesker. Normer for samhandling bygger da på normer for vennskap og kjærlighet. Ansvar og deling blir stående som viktige moralkategorier (Benhabib 1992: 159). Benhabib lanserer det hun kaller en interaktiv universalisme som anerkjenner at alle generaliserte andre også er konkrete andre. Hun ønsker derfor en diskursetikk som ikke tar utgangspunkt i en hypotetisk tankeprosess slik Rawls gjør gjennom sine begreper opprinnelige posisjon og uvitenhetens slør, men Benhabib ønsker en virkelig dialogsituasjon der agentene er «embedded and embodied». Å dømme rasjonelt er ikke å dømme som om en var uvitende om det en vet. Å dømme rasjonelt er å dømme i lys av all tilgjengelig og relevant informasjon (Benhabib 1992: 169). Gjennom sitt bidrag til en diskursetikk prøver Benhabib å oppheve det strenge skillet mellom rettferdighet og det gode liv, mellom normer og verdier og mellom behov og interesser. Benhabib ser disse dikotomiene som modne for revisjon. I fotballfellesskapet betyr det at tiden fordeles etter en åpen dialog mellom konkrete agenter hvor både ulikheter i behov, ønsker og bakgrunn er 
relevante: «[...] uten engasjement, konfrontasjoner, dialog eller også en kamp for anerkjennelse i Hegelsk forstand, skaper vi den andres annethet gjennom projeksjoner, fantasi eller vi overser den andre gjennom vår likegyldighet» (Benhabib 1992: 168). ${ }^{3}$

Svakheten i Benhabibs diskursive etikk er at den ikke har utviklet en teori om fordeling. Vi står derfor igjen med diskursen - og vil vi med dette få en konsensus når det gjelder spilletid for spillerne? I det aktuelle fotballlaget er spillerne nå trukket inn i en diskusjon om fordeling av spilletid. De er enige om at alle spillere skal få spille i kamper, og at den tidligere fordelingen av tid var urettferdig. Dette var også foreldrenes utgangspunkt for kravet om ny fordeling. Spillerne er imidlertid ikke enige om hvor mye den enkelte skal spille, men de ønsker seier der dette er mulig, og innser derved at treneren må kunne fordele tiden ulikt på ulike spillere. Mange har også tatt til orde for at god innsats på treningene bør være ett av kriteriene for spilletid.

\section{Innsats og talent: Personlig ansvar eller heldige omstendigheter}

Ronald Dworkin skiller i sin rettferdighetsteori mellom valg og omstendigheter som utgangspunkt for fordeling. ${ }^{4}$ Sosiale omstendigheter er ikke selvvalgt, og man kan ikke forventes å stå til ansvar for dem. Valg, derimot, er man selv ansvarlig for. Under kategorien valg setter Dworkin (2003: 192) underkategoriene ambisjoner og karakter. Overført til den konkrete fotballkamp kan vi med Dworkin si at foreldres bidrag til fotballen i form av penger eller ekstra dugnadsinnsats ikke kan være et kriterium for økt spilletid, ettersom man hverken velger sine foreldre eller sin familiebakgrunn. Det som derimot kan være relevant for forskjellsbehandling, er deltakelse på trening, intensitet i kamper og ambisjonsnivå. Ifølge Dworkin er det talentet en person har, også et utfall av ikke-valgte omstendigheter. Etter min mening er det imidlertid vanskelig å kunne skille ut det medfødte, ikke-valgte talentet fra de kvalifikasjonene man har oppnådd gjennom hardt arbeid. ${ }^{5}$ Guttene selv mener at talent koblet med arbeidsinnsats bør telle ved fordelingen av spilletid. De som har godt oppmøte og god innsats på trening, bør premieres med ekstra tid, mens de som ikke gidder å komme eller å yte sitt beste, bør straffes med redusert tid. Det vil også kunne brukes som ytre motivasjon for videre trening, ettersom innsats vil være enda mer avgjørende i årene som kommer.

Fra Dworkins teori om valg og omstendigheter som utgangspunkt for fordeling av goder, skal vi over på et felt for rettferdig fordeling som om mulig er enda vanskeligere å definere: spillernes preferanser. 


\section{Ulike preferanser om spilletid}

Vi har til nå diskutert rettferdig fordeling av et gode, nemlig spilletid, ut fra den antakelsen at alle spillere ønsker mest mulig spilletid. Det er imidlertid ikke sikkert dette er riktig. En standard som brukes av politikere og økonomer for å måle rettferdighet, er oppfyllelse av preferanser. De som har det høyeste nivået av preferanseoppfyllelse, kommer best ut. Preferanser er en subjektiv størrelse (i motsetning til en sum penger eller antall minutter). På vårt fotballag er det mulig at ikke alle spillerne har de samme preferansene for ønsket spilletid, og det vil påvirke utfallet for hvor fornøyd den enkelte er med sine tilmålte minutter på fotballbanen. Det er derfor mulig å sette spørsmålstegn ved ulike forhold med hensyn til spillernes preferanser og holdninger. To sentrale spørsmål vil være:

1 Ønsker alle spillerne like mye spilletid?

2 Hvordan fordeler skuffelsen seg ved en tapt kamp?

Kanskje er det noen spillere som ønsker mindre spilletid. Motivene kan være av ulik art, for eksempel at ønsket om å vinne kampen overstiger ønsket om å spille mest mulig, eller at de fort blir slitne, eller at de ikke synes det er så gøy å spille fotball. Her må det imidlertid tas i betraktning at preferanser kan være adaptive (Sen 1999: 62; Nussbaum 2005: 34). Det vil si at hvis disse spillerne er blitt vant til alltid å få mindre spilletid, kan deres $ø$ nker ha justert seg etter forventningene. Min hypotese som følger spørsmål 2, er at de som legger ned mest innsats, også er de som blir mest skuffet. Personlighetsforskjeller vil selvfølgelig også spille inn, men på dette laget ser vi en sammenheng mellom motivasjon for seier og innsats under kamp. Tapet går derfor hardest ut over de mest energiske. Det er imidlertid meget vanskelig å definere ønsker om spilletid og grad av skuffelse. Amartya Sen (1999) kritiserer preferanser som utgangspunkt for rettferdig fordeling av flere grunner. Én av grunnene er at preferanser kan være adaptive, og en annen viktig grunn er at noen har krevende preferanser, mens andre har preferanser på et lavere nivå. Er det rettferdig at de med de krevende preferansene skal ha like stor grad av preferanseoppfyllelse som de med mindre krevende preferanser (jf. Sen 1999: 64)? Er det rettferdig at de som har preferanser om å få spille nesten hele tiden, får oppfylt dette når det går på bekostning av spilletiden til de som ikke har de samme høye preferansene? Alle blir fornøyde, men noen får veldig lite spilletid sammenliknet med andre.

\section{Like muligheter}

Et alternativ til fordeling etter preferanser og primærgoder er det som kalles «capability approach», som vi kan oversette med mulighetstilnær- 
ming. Amartya Sens forsvar av en slik tilnærming er samtidig en kritikk av utilitarismens upersonlige syn på fordeling. Ifølge utilitarismen kan det forsvares at enkeltpersoner får en dårligere livssituasjon dersom samfunnet som helhet forbedres. Rawls' rettferdighetsteori tar et oppgjør med den utilitaristiske tanken, men Sen hevder også at Rawls' teori om fordeling av primærgoder å ta for lite hensyn til individuelle forskjeller. De ulike rettferdighetsteoriene legger for stor vekt på materielle goder eller preferanser som variabler for rettferdighet, ifølge Sen. Menneskers frihet til å kunne bruke sine muligheter er viktigere enn stadig å få det bedre økonomisk. Denne friheten er en kombinasjon av materielle og immaterielle forutsetninger (Sen 1999: 68). ${ }^{6}$ Sens tilnærming til rettferdighet gjennom muligheter skaper også noen problemer som er vanskelige å overkomme. I et hav av muligheter, hvordan skal man fastsette de vesentlige mulighetene? Sen (1999: 75) definerer de vesentlige muligheter som det mennesker har grunn til å verdsette eller til å ønske å oppnå. Martha Nussbaum (2005) går et skritt videre og lister opp de viktigste mulighetene. Hennes liste er et forsøk på å gi en sammenliknende standard for å måle livskvalitet. De viktigste mulighetene mennesker har, handler ifølge Nussbaum om liv og helse. Overført til administrering av fotballaget vil det si at man ikke lar et mål om seier gå på bekostning av spillernes helse. Nussbaum vektlegger videre det å ha følelser for andre, å legge planer for sitt liv og å ha mulighet for lek og moro. Den følelsesmessige utviklingen skal ikke ødelegges av angst og bekymring (Nussbaum 2005: 41).

Mange fotballag preges av spillernes angst for å gjøre feil, av raseri og av beskyldninger av medspillere ved tap. Målet er å bygge et lag preget av lekenhet og medansvar, hvor spillerne kan delta i planleggingen av kampene. Det gjelder selvfølgelig ikke bare fordelingen av spilletid, men også hvordan man bygger opp lagånd i fotballsamfunnet. Vi må ta høyde for personlige, kulturelle og kjønnsmessige forskjeller, og se på eventuelle undertrykkende mekanismer i laget. Det er ikke bare å vinne som er viktig. Vekst er en dårlig indikator på livskvalitet fordi den ikke måler hvor undertrykt mennesker er (Nussbaum 2005: 33).

\section{Kjonn og rettferdig fordeling}

Laget er som nevnt et rent guttelag. Det består av mange ulike individer, med store individuelle forskjeller, men det kan allikevel grovt deles opp i to personlighetskategorier. Disse kategoriene gjenspeiler på mange måter en tradisjonell oppdeling i feminine og maskuline personlighetstyper. Ettersom laget kun består av gutter, har jeg valgt å bruke betegnelsene kategori 1 og 2. Den første kategorien er forholdsvis rolige spillere, mens den andre kategorien domineres av spillere som er røffere i stilen. De typiske representantene for sistnevnte kategori er spillere som roper mye og som ved tap 
alltid kritiserer dommeren. ${ }^{7}$ Forskjellen kommer tydelig fram når spillerne er innbyttere. Spillere i kategori 1 vil som regel vente rolig på sin tur, mens representanter for kategori 2 vil mase helt til de får lov å spille. Det er derfor lett å overse kategori 1 og å la kategori 2 spille mest.

Det ligger en del uutalte forventninger til hvordan en fotballspiller skal oppføre seg, blant annet at man skal være pågående. Jeg vil anta at de pågående fortballspillerne i større grad sees på som gode fordi de går inn i kampen med tilsynelatende høy selvtillit. Gjennom en dikotomisering av gruppene er det en fare for at kategori 1 defineres som en motsetning til kategori 2 ut fra det som forventes av adferd hos en fotballspiller. Kategori 1 blir derfor hva kategori 2 ikke er (og hva en fotballspiller ikke forventes å være) nemlig passiv, ikke-konkurrerende, sårbar og pysete - mens kategori 2 blir idealet (og hva en fotballspiller forventes å være) - nemlig aktiv, konkurrerende og tøff. I denne dikotomiseringen vil det ligge et usynlig forsvar av den pågående gruppens krav om mest spilletid. Samtidig kan forventingene til hvordan de ulike kategoriene av spillere skal oppføre seg føre til en forsterkning og ytterligere dikotomisering av kategoriene, som igjen kan virke på gruppenes ulike preferanser (jf. Sens diskusjon om adaptive preferanser).

Martha Nussbaum hevder at kjønnsrettferdighet ikke kan utøves vellykket uten å begrense menns frihet. Overført til vår sammenheng, må «menn» leses som kategori 2 fotballspillere (og «kvinner» er kategori 1). Ifølge Nussbaums teori må vi begrense kategori 2 i deres iver etter å spille for at vi skal oppnå likestilling mellom de to gruppene på fotballbanen. Grunnen er at kategori 1 har vært forfordelt på grunn av sin manglende pågående adferd på sidelinja. Et liknende forhold kan vi finne når det gjelder kulturforskjeller.

\section{Anerkjennelse av fotballkulturelle forskjeller}

Fotballaget jeg har sett på, består av barn med svært ulik fotballkulturell bakgrunn. Noen er vokst opp i «Vål'engaklanen» hvor fotball er «relion», mens andre er fra hjem med et mer distansert forhold til fotball. De fotballinteresserte foreldrene vil i større grad stille opp på kamper og dugnader. De behersker fotballspråket godt, og de har bedre forutsetninger for å påvirke og delta i fotballsamfunnet. Er disse kulturforskjellene en grunn til å forskjellsbehandle? På den ene siden kan man si at det er grunn til å framheve de som ikke kommer fra fotballinteresserte miljøer, mens på den annen side kan man si at i de fotballinteresserte miljøene vil kanskje fotballen bety ekstra mye. Goder har ulik kulturell betydning (Walzer 1983: 5). Spilletid vil derfor muligens være ekstra viktig innenfor visse miljøer, og upartiskhet nødvendigvis ikke det mest rettferdige.

Hvis vi allikevel forutsetter at det er spillerne fra ikke-fotballinteresserte hjem som marginaliseres i fotballmiljøet, kan det være aktuelt med kvote- 
ring for å motvirke disse systemiske urettferdighetene. Det er stor uenighet om hvor mye vekt man skal legge på kulturforskjeller. Vil det å framheve, eventuelt kvotere inn, spillere på grunnlag av kulturbakgrunn for å motvirke tidligere urettferdighet gå på bekostning av spillernes individuelle forskjeller? Den canadiske filosofen Charles Taylor (1994) tilnærmer seg rettferdighet ved å formulere anerkjennelsens politikk - «the Politics of Recognition». Taylor hevder at mennesker har rett til å forme og definere sin identitet som individ, men også som kultur. Det er en innfallsvinkel som vektlegger anerkjennelse av ulikhet. Det er derfor ikke bare individuelle forskjeller som skal anerkjennes, men også ulik gruppetilhørighet (Taylor 1994: 41). Det betyr i praksis at det kan forsvares å bruke mer ressurser på minoritetsgrupper.

Dersom kjønn og kultur kobles sammen i denne analysen, kan vi si at den prototypiske fotballspilleren - og derfor den som kommer lettest til er en spiller fra kategori 2 med foreldre med fotballbakgrunn. Det kan derfor være et poeng å bruke mer ressurser på å fă fram spillere fra kategori 1 som ikke har fotballkulturell bakgrunn i laget.

\section{Konklusjon}

Med denne gjennomgangen av ulike rettferdighetsteorier står jeg igjen med spørsmålet om hvilke argumenter jeg skal la telle med ved fordeling av spilletid og derved hvilke rettferdighetsteorier som blir mest aktuelle.

Gjennom den foregående diskusjonen har jeg lagt vekt på ulike individog gruppehensyn ved fordeling av spilletid. Spillerne er delt inn i grupper etter hvor gode de er, hvor entusiastiske de er, om de er rolige eller bråkete, hvilken fotballbakgrunn de har, og hvilke personlige preferanser de har. Jeg har gjennom rettferdighetsteoriene prøvd å tenke på hver enkelt spillers opplevelse av spilletid og resultater. Fotballspill er imidlertid først og fremst et lagspill, og lagets samlede innsats bør derfor veie tyngre enn hensynet til enkeltindividet, dog ikke på bekostning av individet. Jeg ser derfor på MacIntyres bruk av begrepet practice, kommentert i innledningen, som et fruktbart tilskudd til rettferdighetsteoriene i denne konteksten. Forstår vi fotballspillet på denne måten, er det lagspillet og ikke enkeltprestasjoner eller hensynet til den enkeltes spilletid som veier tyngst. Lagleder og trener skal gå sammen om å utvikle laget slik at de oppnår de interne godene ved fotballpraksisen, nemlig perfeksjoneringen av spillet og samarbeidet om å vinne en kamp. Det gjelder imidlertid først og fremst som en rettesnor for treningene. I fotballkampens hete er det seier som gjelder. Seieren må imidlertid ikke slå foten under prinsippene for laget og treningene, men muligens er det andre regler som gjelder under kamp. Jeg har argumentert for at en helt lik fordeling av spilletid bryter med det aristoteliske rettferdighetsprinsip- 
pet om at ulikemenn skal behandles ulikt. Den vanskelige vurderingen blir imidlertid hva som skal tas hensyn til av behov, interesser, evner, resultater, personlighetskategorier og kulturforskjeller.

For å vinne kreves det at eksterne goder som det å score mål oppfylles. Det vil si at hensynet til både hvilke spillere som klarer de ulike posisjonene i spillet best samt innsatsen under kampen må tas i betraktning. Det er imidlertid lite motiverende å bli satt på benken $i$ alle kamper, og dessuten strider det mot kritikken som innledet diskusjonen om ny fordeling av spilletid. Spillere som trener regelmessig og intensivt, vil fort bli demotiverte ved lite kampspill. Jeg anser derfor at et terskelnivå som det Sen og Nussbaum argumenterer for, kan være det beste under kamp. Alle spillere får spille et visst antall minutter. I Benhabibs ånd kan guttene være med på å bestemme dette terskelnivået gjennom diskusjon. Jeg har ingen tro på et rawlsk «uvitenhetens slør» over en slik fordelingsdiskusjon. Derimot anser jeg spillerne som fornuftige, hensynsfulle og egoistiske. De ønsker å vinne. Noen vet, eller tror de vet, at de kan redde de fleste kamper, mens de fleste vet at innsatsen varierer fra kamp til kamp. Ved å ta del i en diskusjon om fordelingen av spilletid vil guttene få både en viss innsikt i rettferdighetstenkning samt en forståelse av hvorfor fordelingen blir som den blir i en gitt kamp. Kampminuttene utover terskelnivået bør fordeles etter en aristotelisk brøk, hvor innsats og prestasjoner belønnes med ekstra antall minutter. Personlighetskategorier og kulturforskjeller bør i denne sammenhengen ikke være relevant annet enn for trenerens egen bevissthet om fordommer og preferanser for å fremme høyest mulig grad av upartiskhet.

\section{Noter}

1 NFF definerer topping som at «noen får vesentlig mer spilletid enn andre»: www.fotball.no/Barn_og_ungdom/Barnefotball/Retningslinjer/Barnefotballens-verdigrunnlag/ (Norges fotballforbund 2009a: 59). I NFFs dokument Barnefotball: Verdier og virkemidler. Et hefte for deg som jobber med barn mellom 6-12 ar lansert i februar 2010, opprettholdes prinsippet om lik spilletid: «Gjennom en sesong skal alle spille like mye» (Norges fotballforbund 2010: 9). I retningslinjene for ungdomsfotballen manes trenere til å utvise godt skjønn, men reguleringene som gjelder for barneidretten, er borte: www.fotball.no/Barn_og_ungdom/Ungdomsfotball/Retningslinjer/Retningslinjer-for-ungdomsfotballen/

2 Forklaringene på frafallet som begynner ved overgang til 11'er og fortsetter gjennom ungdomstiden, kan være mange. Ole Ivar Storø konkluderer imidlertid i rapporten Du og jeg og vi to: en kvalitativ og komparativ studie av konkurranse, deltakelse og relasjoner mellom to jentelag i ungdomsfotball (2007) at på det laget trenerne la stor vekt på talentutvikling var det flere spillere som sluttet på laget enn på det laget der de satset mest på bredde. (SIFO (2007): fagrapport: http://www.sifo.no/files/file72 767_fagrapport2007-3web.pdf 
3 Min oversettelse fra Benhabib (1992: 168): «Without engagement, confrontation, dialogue and even a «struggle for recognition» in the Heglian sense, we tend to constitute the otherness of the other by projection and fantasy or ignore it in indifference.»

4 Dworkin bruker begrepene choice og circumstance

5 Samuel Scheffler (2003: 17) kritiserer Dworkin for å være en representant for det han litt nedlatende kaller lykke-egalitarianisme (luck-egalitarianism). Han anser også distinksjonen mellom valg og omstendighet som særdeles problematisk.

6 «The capability approach» er innflytelsesrik i frivillige organisasjoner og har påvirket verdensbankens arbeid med terskelnivåer.

7 Dette er en stereotypisering av gruppene. Jeg spiller med vilje på kjønnsstereotypier og mener at kjønnsteorier om makt også kan passe inn i kjønnshomogene sammenhenger.

\section{Litteratur}

Aristoteles. (1973) Etikk: Et hovedverk i Aritoteles' filosofi, også kalt «Den Nikomakiske etikk». Oslo: Gyldendal.

Benhabib, S. (1992) The generalized and the concrete other. I Situating the self: Gender, community and postmodernism in contemporary ethics. Cambridge: Polity Press.

Dworkin, R. (2003) Equality, luck and hierarchy. Philosophy and Public Affairs, 31 (2), s. 190-198.

Elster, J. (1990) Lokal rettferdighet. Hvordan institusjoner fordeler knappe goder. Nytt Norsk Tidsskrift, 7, s. 325-337.

Feinberg, J. (1973) Social philosophy. Englewood Cliffs, NJ: Prentice Hall.

MacIntyre, A. (1981/1985) After virtue. London: Duckworth.

Norges fotballforbund (2009a) Barnefotballens verdigrunnlag. Lastet ned 8.september 2009 fra http://www.fotball.no/Barn_og_ungdom/Barnefotball/ Retningslinjer/Barnefotballens-verdigrunnlag/

Norges fotballforbund (2009b) Retningslinjer for ungdomsfotballen. Lastet ned 8. september 2009 fra http://www.fotball.no/Barn_og_ungdom/Ungdomsfotball/ Retningslinjer/Retningslinjer-for-ungdomsfotballen/

Norges fotballforbund (2010) Barnefotball: Verdier og virkemidler. Et hefte for deg som jobber med barn mellom 6-12 år. Lastet ned 30.03.2010 fra http:// www.fotball.no/Barn_og_ungdom/Barnefotball/2010/Barnefotballbrosjyren2010/

Nussbaum, M. (2005) Capabilities as fundamental entitlements: Sen and social justice. I Amartya Sens work and ideas: A gender perspective, red. B. Agarwal, J. Humphries \& I. Robeyns. London: Routledge.

Rawls, J. (2001) Justice as fairness. A restatement. Cambridge, MA: Harvard University Press.

Scheffler, S. (2003) What is egalitarianism? Philosophy and Public Affairs, 31 (2), s.199-206.

Sen, A. (1999) Freedom as development. Oxford: Oxford University Press.

Storø, O.L. (2007) Du og jeg og vi to: En kvalitativ og komparativ studie av konkurranse, deltakelse og relasjoner mellom to jentelag $i$ ungdomsfotball. Fagrapport 
SIFO. Lastet ned 8. september 2009 fra www.sifo.no/files/file72 767_fagrapport2007-3web.pdf.

Taylor C. (1994) The politics of recognition. I Multiculturalism, red. A. Gutmann. Princeton, NJ: Princeton University Press.

Walzer, M. (1983) Spheres of justice: A defense of pluralism and equality. New York: Basic Books. 